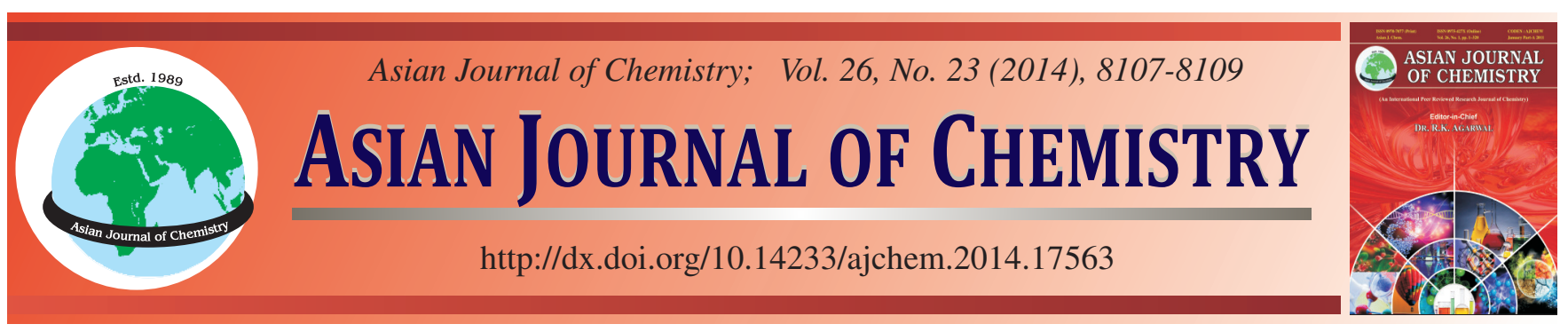

\title{
Synthesis and Characterization and Crystal Structure of New Oxime-Type Mononuclear Nickel(II) Complex with 1-[4-((E)-4-Methoxyl-2-hydroxybenzylidene)]oxime
}

\author{
L. ZhaO ${ }^{*}$ P. WANG, Q. Cheng, H.-X. GuO and X.-L. YAN
}

School of Chemical and Biological Engineering, Lanzhou Jiaotong University, Lanzhou 730070, P.R. China

*Corresponding author: E-mail: zhaoli_72@163.com

Received: 6 March 2014;

Accepted: 22 May 2014;

Published online: 15 November 2014;

AJC-16305

\begin{abstract}
A new $\mathrm{Ni}(\mathrm{II})$ complex, $\left[\mathrm{Ni}(\mathrm{L})_{2}\right]$, has been synthesized via the complexation of nickel(II) acetate monohydrate with a new oxime-type ligand (HL =1-[4-((E)-4-methoxyl-2-hydroxybenzylidene)]oxime). X-ray crystal structure determination of the Ni(II) complex shows that the $\mathrm{Ni}(\mathrm{II})$ complex is mononuclear, the $\mathrm{Ni}(\mathrm{II})$ atom is four-coordinated by the phenolate $\mathrm{O}$ atoms and imine $\mathrm{N}$ atoms from two deprotonated oxime-type ligands $\mathrm{L}$, in a square-planar geometry.
\end{abstract}

Keywords: Oxime-type compound, Synthesis, Crystal structure.

\section{INTRODUCTION}

As is well known, Schiff base compounds have been playing an important role in the development of coordination chemistry ${ }^{1,2}$. During the past few years, a large number of Schiff base complexes have been studied extensively for there facile synthesis and easily tunable steric position and application ${ }^{3}$. Many Schiff base complexes have been structurally characterized $^{4}$, but only a relatively small number of oxime-type compounds have been characterized ${ }^{5-7}$. Here, we report the synthesis and crystal structure of a new oxime-type Ni(II) complex.

\section{EXPERIMENTAL}

4-Methoxyl-2-hydroxybenzylidene and hydroxylamine hydrochloride were purchased from Alfa Aesar and used without further purification. The other reagents and solvents were analytical grade reagents from Tianjin Chemical Reagent Factory.

Elemental analysis for Ni was detected by an IRIS ER/S.WP$1 \mathrm{ICP}$ atomic emission spectrometer. $\mathrm{C}, \mathrm{H}$ and $\mathrm{N}$ analyses were carried out with a GmbH VariuoEL V3.00 automatic elemental analyzer. IR spectra were recorded on a VERTEX70 FT-IR spectrophotometer, with samples prepared as $\mathrm{KBr}\left(4000-500 \mathrm{~cm}^{-1}\right)$ and CsI (500-100 $\left.\mathrm{cm}^{-1}\right)$ pellets. UV-visible absorption spectra were recorded on a Shimadzu UV-2550 spectrometer. X-ray single crystal structure was determined on a Bruker Smart 1000 CCD area detector. Melting points were obtained by use of an $\mathrm{X}_{4}$ microscopic melting point apparatus made in Beijing Taike Instrument Limited Company and were uncorrected.
Synthesis of HL: To a hot water $(4 \mathrm{~mL})$ solution of hydroxylamine hydrochloride $(73.35 \mathrm{mg}, 1.1 \mathrm{mmol})$ was added sodium bicarbonate $(84 \mathrm{mg}, 1 \mathrm{mmol})$. The solution is clarified and added an ethanol (4 mL) solution of 4-methoxyl2-hydroxybenzylidehe after stirring the reaction mixture at $338 \mathrm{~K}$ for $5 \mathrm{~h}$. The solvent was removed under reduced pressure and the residue was recrystalized form ethanol to give the title compound HL. Yield 77.4 \%. m.p. 438-439 K. Anal. Calcd. for $\mathrm{C}_{8} \mathrm{H}_{9} \mathrm{NO}_{3}(\%)$ : C, 57.48; $\mathrm{H}, 5.43 ; \mathrm{N}, 8.38$. Found (\%): C, 57.45; H, 5.36; N, 8.44.

Synthesis of the Ni(II) complex: A solution of nickel(II) acetate monohydrate $(2.5 \mathrm{mg}, 0.01 \mathrm{mmol})$ in methanol $(2 \mathrm{~mL})$ was added dropwise to a solution of HL (3.3 mg, $0.02 \mathrm{mmol})$ in methanol $(5 \mathrm{~mL})$ at room temperature. The colour of the mixing solution turned to brown immediately and then continued to stirring for $4 \mathrm{~h}$ at room temperature. The mixture solution was filtered and the filtrate was allowed to stand at room temperature for about four weeks, the solvent was partially evaporated and obtained several green prismatic single crystals suitable for X-ray crystallographic analysis. Anal. Calcd. for $\mathrm{C}_{16} \mathrm{H}_{16} \mathrm{~N}_{2} \mathrm{O}_{6} \mathrm{Ni}\left\{\left[\mathrm{Ni}(\mathrm{L})_{2}\right]\right\}(\%)$ : C, 49.15; H, 4.12; N, 7.16; Ni, 15.01. Found: C, 49.32; H, 4.09; N, 6.96; Ni, 15.13 .

$\mathrm{X}$-ray structure determination: Details of the crystal parameter, data collection and refinements for the Ni(II) complex are summarized in Table- 1 .

The X-ray diffraction measurement for the Ni(II) complex was performed on Bruker Smart 1000 CCD diffractometer with graphite monochromated $\mathrm{MoK}_{\alpha}$ radiation $(\lambda=0.071073$ $\mathrm{nm})$ at 298(2) K. Empirical absorption correction was applied 


\begin{tabular}{|c|c|}
\hline \multicolumn{2}{|c|}{$\begin{array}{c}\text { TABLE-1 } \\
\text { CRYSTAL DATA AND STRUCTURE } \\
\text { REFINEMENT FOR THE Ni(II) COMPLEX }\end{array}$} \\
\hline Empirical formula & $\mathrm{C}_{16} \mathrm{H}_{16} \mathrm{~N}_{2} \mathrm{O}_{6} \mathrm{Ni}$ \\
\hline Formula weight & 391.02 \\
\hline Temperature (K) & 298(2) \\
\hline Wavelength $(\AA)$ & 0.71073 \\
\hline Crystal system & Monoclinic \\
\hline Space group & $\mathrm{P} 2(1) / \mathrm{c}$ \\
\hline Cell dimensions, $(\AA$, deg $)$ & $\begin{array}{l}a=6.4406(8), b=18.356(2) \\
c=8.2859(11) \\
\beta=124.633(2)\end{array}$ \\
\hline Volume $\left(\AA^{3}\right)$ & $806.02(18)$ \\
\hline $\mathrm{Z}$ & 2 \\
\hline Density (calculated) $\left(\mathrm{mg} / \mathrm{m}^{3}\right)$ & 1.611 \\
\hline Absorption coefficient $\left(\mathrm{mm}^{-1}\right)$ & 1.240 \\
\hline $\mathrm{F}_{(000)}$ & 404.0 \\
\hline Crystal size & $0.28 \times 0.11 \times 0.07$ \\
\hline Index ranges & $-7 \leq \mathrm{h} \leq 7,-20 \leq \mathrm{k} \leq 21,-9 \leq 1 \leq 7$ \\
\hline Reflections collected & $3980\left(\mathrm{R}_{\mathrm{int}}=0.0775\right)$ \\
\hline Independent reflections & 1419 \\
\hline Reflections observed $[\mathrm{I}>2 \sigma(\mathrm{I})]$ & 824 \\
\hline Data/restraints/parameters & $1419 / 0 / 116$ \\
\hline Goodness of fit indicator & 1.034 \\
\hline $\mathrm{R}[\mathrm{I}>2 \sigma(\mathrm{I})]$ & $\mathrm{R}_{1}=0.0600, \mathrm{wR}_{2}=0.1193$ \\
\hline Largest diff. peak and hole $\left(\mathrm{e} \AA^{-3}\right)$ & $0.645,-0.828$ \\
\hline
\end{tabular}

to the data using SADABS program. The structure was solved by direct methods and refined by full-matrix least-squares method on $\mathrm{F}^{2}$ using the SHELXL program. All non-hydrogen atoms were refined anisotropically. All the hydrogen atoms were generated geometrically and refined isotropically using the riding model. CCDC: 989207.

\section{RESULTS AND DISCUSSION}

FT-IR spectra: The main FT-IR spectral data of the free ligand HL and its corresponding Ni(II) complex in the 4000$400 \mathrm{~cm}^{-1}$ region is given in Fig. 1 .

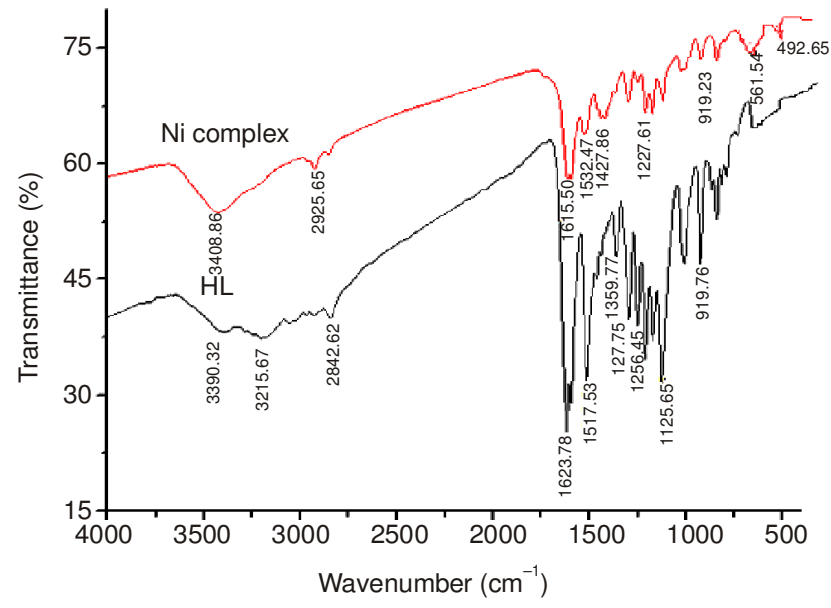

Fig. 1. FT-IR spectra of the free ligand HL and its Ni(II) complex

The free ligand HL exhibits characteristic $(\mathrm{C}=\mathrm{N})$ stretching band at $1623.78 \mathrm{~cm}^{-1}$, while the $(\mathrm{C}=\mathrm{N})$ stretching band of the $\mathrm{Ni}$ (II) complex was observed in the $1615.50 \mathrm{~cm}^{-1}$. The $(\mathrm{C}=\mathrm{N})$ stretching frequency is shifted to lower frequency by about $8 \mathrm{~cm}^{-1}$ upon complexation, indicating the behavior between the free ligand and the corresponding $\mathrm{Ni}$ (II) atom resulting in weakening the force constant of $\mathrm{C}=\mathrm{N}$ bond. Meanwhile, the Ar-O stretching frequency appears as a strong band in the $1256.45 \mathrm{~cm}^{-1}$ in the free ligand HL and the toward lower wavenumber of the Ar-O absorption shift about $29 \mathrm{~cm}^{-1}$ indicating that $\mathrm{Ni}-\mathrm{O}$ bonds are formed between the $\mathrm{Ni}$ (II) atoms and the oxygen atoms of the phenolic groups ${ }^{8,9}$.

The N-O stretching frequencies of the oxime group in the free ligand and its $\mathrm{Ni}$ (II) complex appear as a strong band in the $919.23 \mathrm{~cm}^{-1}$ indicating that the oxime $\mathrm{N}$ atoms do not involve in coordination. In the $1591-1460 \mathrm{~cm}^{-1}$ region, the observed bands were attributed to aromatic $\mathrm{C}=\mathrm{C}$ vibrations. Upon coordination these bands shift to lower frequencies for the $\mathrm{Ni}$ (II) complex. In addition, the $\mathrm{O}-\mathrm{H}$ stretching frequency of the free ligand $\mathrm{HL}$ appears at 3390.32 and $3215.67 \mathrm{~cm}^{-1}$. The out-of-plane bending vibration of phenolic alcohol in the free ligand $\mathrm{HL}$ at $1277 \mathrm{~cm}^{-1}$, which disappears in the $\mathrm{Ni}$ (II) complex, indicating the oxygen in the phenolic alcohol of the $\mathrm{Ni}$ (II) complex has been deprotoned and coordinated to the $\mathrm{Ni}(\mathrm{II})$ atoms.

The far-infrared spectrum of the Ni(II) complex was also obtained in the region $500-100 \mathrm{~cm}^{-1}$ in order to identify frequencies due to the $\mathrm{Ni}-\mathrm{O}$ and $\mathrm{Ni}-\mathrm{N}$ bonds. The FT-IR spectrum of the $\mathrm{Ni}(\mathrm{II})$ complex shows $\mathrm{v}(\mathrm{Ni}-\mathrm{N})$ and $\mathrm{v}(\mathrm{Ni}-\mathrm{O})$ vibration absorption frequencies at 561.54 and $492.65 \mathrm{~cm}^{-1}$, respectively.

UV-visible spectra: The UV-visible absorption spectra of the free ligand HL and its Ni(II) complex in diluted chloroform solution are shown in Fig. 2.

It can be seen that the absorption peaks of the $\mathrm{Ni}$ (II) complex are obviously different from those of the free ligand HL upon complexation. The spectrum of the free ligand HL consists of two relatively intense bands centered at 287.55 and $354.81 \mathrm{~nm}$, assigned to the $\pi-\pi^{*}$ transitions of the benzene ring of the salicylaldehyde and oxime groups ${ }^{10}$. These peaks are shifted to 302.61 and $357.20 \mathrm{~nm}$ in the $\mathrm{Ni}$ (II) complex, respectively and a new absorption peak at $429.22 \mathrm{~nm}$ was observed in the $\mathrm{Ni}$ (II) complex, indicating that the coordination of the Ni(II) atom with the free ligand HL.

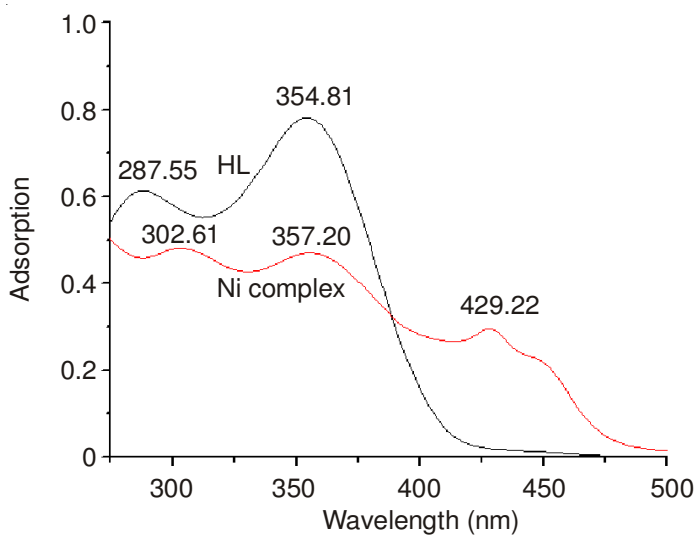

Fig. 2 UV-visible data for the ligand HL and its Ni(II) complex

Crystal structure of $\left[\mathrm{Ni}(\mathrm{L})_{2}\right]$ : X-ray crystallographic analysis of $\left[\mathrm{Ni}(\mathrm{L})_{2}\right]$ reveals formation of a mononuclear structure. The Ni(II) complex crystallizes in the monoclinic system, space group $\mathrm{P} 2(1) / \mathrm{c}$ and $\mathrm{Z}=2$. The $\mathrm{Ni}$ (II) complex consists of one $\mathrm{Ni}$ (II) atom, two bidentate $\mathrm{L}^{-}$units, The molecular structure of the $\mathrm{Ni}$ (II) complex is shown in Fig. 3, selected bond distances and angles are listed in Table-2. 


\begin{tabular}{|c|c|c|c|c|c|}
\hline \multicolumn{6}{|c|}{$\begin{array}{c}\text { TABLE-2 } \\
\text { SELECTED BOND LENGTHS }(\AA) \text { AND ANGLES }\left({ }^{\circ}\right) \text { FOR THE Ni(II) COMPLEX }\end{array}$} \\
\hline Bond & Lengths & Bond & Lengths & Bond & Lengths \\
\hline $\mathrm{Ni1}-\mathrm{O} 2^{\# 1}$ & $1.828(4)$ & Ni1-O2 & $1.828(4)$ & Ni1-N1 & $1.869(4)$ \\
\hline Ni1-N1 ${ }^{\# 1}$ & $1.869(4)$ & - & - & - & - \\
\hline Bond & Angles & Bond & Angles & Bond & Angles \\
\hline $\mathrm{O}^{\# 1}-\mathrm{Ni1}-\mathrm{O} 2$ & 180.0 & $\mathrm{O} 2^{\# 1}-\mathrm{Ni} 1-\mathrm{N} 1$ & $87.3(2)$ & O2- Ni1-N1 & $92.7(2)$ \\
\hline $\mathrm{O} 2^{\# 1}-\mathrm{Ni} 1-\mathrm{N} 1^{\# 1}$ & $92.7(2)$ & $\mathrm{O} 2-\mathrm{Ni} 1-\mathrm{N} 1^{\# 1}$ & $87.3(2)$ & $\mathrm{N} 1-\mathrm{Ni} 1-\mathrm{N} 1^{\# 1}$ & 180.0 \\
\hline C1-N1- Ni1 & $128.9(4)$ & O1-N1- Ni1 & $117.4(3)$ & C3-O2- Ni1 & $129.9(3)$ \\
\hline
\end{tabular}

\begin{tabular}{|c|c|c|c|c|}
\hline \multicolumn{5}{|c|}{$\begin{array}{c}\text { TABLE-3 } \\
\text { DATA FOR HYDROGEN-BONDING INTERACTIONS }\left(\AA{ }^{\circ}{ }^{\circ}\right)\end{array}$} \\
\hline $\mathrm{D}-\mathrm{H} \cdots \mathrm{A}$ & $\mathrm{d}(\mathrm{D}-\mathrm{H})$ & $\mathrm{d}(\mathrm{H} \cdots \mathrm{A})$ & $d(D \cdots A)$ & $\angle \mathrm{D}-\mathrm{H} \cdots \mathrm{A}$ \\
\hline $\mathrm{O} 1-\mathrm{H} 1 \cdots \mathrm{O} 1$ & 0.82 & 2.56 & $3.057(7)$ & 120 \\
\hline $\mathrm{C} 1-\mathrm{H} 1 \mathrm{~A} \cdots \mathrm{O} 1$ & 0.93 & 2.48 & $3.313(8)$ & 149 \\
\hline $\mathrm{O} 1-\mathrm{H} 1 \cdots \mathrm{O} 2$ & 0.82 & 1.87 & $2.496(6)$ & 132 \\
\hline
\end{tabular}

In symmetric molecule unit of the $\mathrm{Ni}(\mathrm{II})$ complex, the $\mathrm{Ni}$ (II) center is tetra-coordinated by the phenolate $\mathrm{O}$ atoms and imine $\mathrm{N}$ atoms from two oxime-type ligands $\mathrm{L}^{-}$, in a squareplanar geometry. The dihedral angle between the coordination plane of O2-Ni1-N1 $1^{\# 1}$ and that of $2^{\# 1}-\mathrm{Ni} 1-\mathrm{N} 1$ is $180^{\circ}$, while another dihedral angle between the coordination plane of N1$\mathrm{Ni1}-\mathrm{O} 2$ and that of $\mathrm{N}^{\# 1}-\mathrm{Ni1}-\mathrm{O} 2^{\# 1}$ is also $180^{\circ}$.

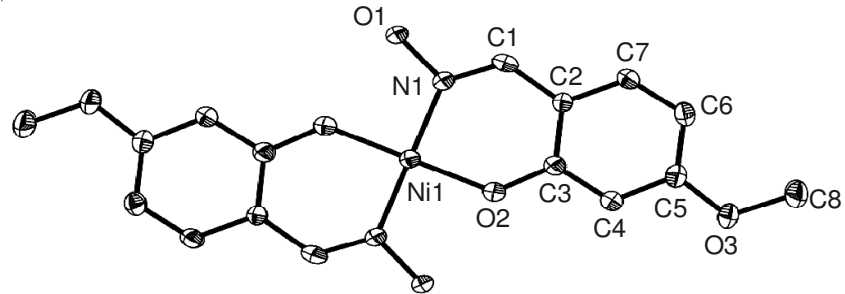

Fig. 3. Crystal structures of the Ni(II) complex with the atom numbering. Thermal ellipsoids are plotted at $30 \%$ probability level. Symmetry code: ${ }^{\# 1}-\mathrm{x}-1,-\mathrm{y}+1,-\mathrm{z}+1$; Hydrogen atoms are omitted for clarity

As illustrated in Fig. 4, There is an intramolecular hydrogen bond $\mathrm{O} 1-\mathrm{H} 1 \cdots \mathrm{O} 2$ between hydroxyl O1-H1 group and phenolic $\mathrm{O} 2$ atom. While the hydroxyl -O1H1 bonded to the phenolate $\mathrm{O} 1$ atom and the -C1H1A group of the oxime-type ligand $\mathrm{L}^{-}$is hydrogen-bonded to the $\mathrm{O} 1$ atom of the phenolate, which are intermolecular hydrogen bonds (Table-3).

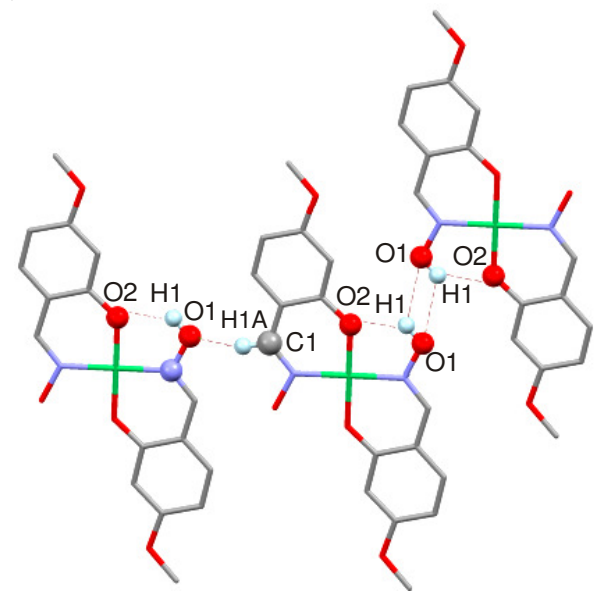

Fig. 4. Molecular hydrogen bonds of the Ni(II) complex. Hydrogen atoms are omitted for clarity

\section{ACKNOWLEDGEMENTS}

This work was supported by the Scientific Research Fund of Gansu Provincial Education Department (20873), which are gratefully acknowledged.

\section{REFERENCES}

1. S.S. Sun, C.L. Stern, S.T. Nguyen and J.T. Hupp, J. Am. Chem. Soc., 126, 6314 (2004).

2. (a) W.K. Dong, S.J. Xing, Y.X. Sun, L. Zhao, L.Q. Chai and X.H. Gao, J. Coord. Chem., 65, 1212 (2012); (b) W.K. Dong, Y.X. Sun, S.J. Xing, Y. Wang and X.H. Gao, Z. Naturforsch, 67b, 197 (2012); (c) W.K. Dong, X.N. He, H.B. Yan, Z.W. Lv, X. Chen, C.Y. Zhao and X.L. Tang, Polyhedron, 28, 1419 (2009); (d) W.K. Dong, Y.X. Sun, C.Y. Zhao, X.Y. Dong and L. Xu, Polyhedron, 29, 2087 (2010); (e) W.K. Dong, X.N. He, H.B. Yan, Z.W. Lv, X. Chen, C.Y. Zhao and X.L. Tang, Polyhedron, 28, 1419 (2009); (f) W.K. Dong, Y.X. Sun, G.H. Liu, L. Li, X.Y. Dong and X.H. Gao, Z. Anorg. Allg. Chem., 638, 1370 (2012); (g) W.K. Dong, K.Q. Li, Y. Zhang, L. Xu, L. Wang and X.Y. Dong, Asian J. Chem., 25, 4398 (2013).

3. S. Akine, T. Taniguchi and T. Nabeshima, Angew. Chem. Int. Ed., 41, 4670 (2002).

4. D.A. Atwood and M.J. Harvey, Chem. Rev., 101, 37 (2001).

5. W.K. Dong, G. Wang, S.S. Gong, J.F. Tong, Y.X. Sun and X.H. Gao, Transit. Met. Chem., 37, 271 (2012).

6. P.A.N. Reddy, R. Datta and A.R. Chakravarty, Inorg. Chem. Commun., 3, 322 (2000).

7. M.S. Ray, R. Bhattacharya, S. Chaudhuri, L. Righi, G. Bocelli, G. Mukhopadhyay and A. Ghosh, Polyhedron, 22, 617 (2003).

8. V.H. Kulkarni, B.R. Patil and B.K. Prabhakar, J. Inorg. Nucl. Chem., 43, 17 (1981).

9. M. Asadi, K.A. Jamshid and A.H. Kyanfar, Inorg. Chim. Acta, 360, 1725 (2007).

10. S. Akine, Y. Morita, F. Utsuno and T. Nabeshima, Inorg. Chem., 48 , 10670 (2009). 